\title{
Safety and long-term effect of the probiotic FK-23 in patients with hepatitis $\mathrm{C}$ virus infection
}

\author{
Khin May OO'1, Aye Aye Lwin'1, Yi Yi KYAW¹, Win Maw TUN¹, Kazutake FUKADA², Akiko GOSHIMA², \\ Takashi SHIMADA ${ }^{2,3^{*}}$ and Shigeru OKADA ${ }^{4}$ \\ ${ }^{1}$ Department of Medical Research (Lower Myanmar), No. 5 Ziwaka Road, 11191 Yangon, Republic of the Union of Myanmar \\ ${ }^{2}$ Central Research Laboratories, Nichinichi Pharmaceutical Corporation Ltd., 239-1 Tominaga, Iga City, Mie 518-1417, Japan \\ ${ }^{3}$ Department of Gastrointestinal Immunology, Kyoto Prefectural University of Medicine, Kamigyo-ku, Kyoto 602-8566, Japan \\ ${ }^{4}$ Graduate School of Medicine, Dentistry and Pharmaceutical Sciences, Okayama University, 2-6-7 Bancho, Kita-ku, Okayama \\ 700-0811, Japan
}

Received December 14, 2015; Accepted April 12, 2016; Published online in J-STAGE May 2, 2016

\begin{abstract}
A clinical trial was conducted on 39 adult $\mathrm{HCV}$-positive subjects to determine the safety and long-term effect of the probiotic FK-23 (heat-treated Enterococcus faecalis strain FK-23). Asymptomatic anti-HCV positive adults who fulfilled the selection criteria and gave voluntary consent were recruited from attendees of the Hepatitis Carrier Clinic, Department of Medical Research (Lower Myanmar). Each subject was given 2,700 mg of FK-23 per day by oral route. Blood samples were taken at enrollment and every 3 months and tested for alanine aminotransferase (ALT) and aspartate transaminase (AST). Viral load, urea, total protein, hemoglobin and platelet count were determined every 6 months. Among the subjects, 23 completed 36 months, 31 completed 24 months, 35 completed 12 months and 37 completed 6 months of probiotic therapy. Significant decreases in mean ALT levels were observed at 3 months (34.9 \pm 15.1 IU/I) as compared with the initial level $(64.8 \pm 17.5 \mathrm{IU} / \mathrm{l})$ and persisted up to 36 months $(43.7 \pm 25.2 \mathrm{IU} / \mathrm{l})$. Decrease of AST was detected after 9 months $(46.2 \pm 21.7 \mathrm{IU} / \mathrm{l})$ of probiotic therapy as compared with the initial level $(64.3 \pm$ 28.7 IU/l). FK-23 was safe based on the stable levels of biochemical and hematological parameters and the absence of untoward side effects. The FK-23 preparation was well tolerated and accepted by the subjects.
\end{abstract}

Key words: probiotic, alanine aminotransferase (ALT), aspartate transaminase (AST), Enterococcus faecalis FK-23

\section{INTRODUCTION}

Hepatitis $\mathrm{C}$ virus $(\mathrm{HCV})$ infection is a global health problem. The World Health Organization (WHO) has estimated that as many as 170 million persons worldwide may be infected. Although the virus infection is usually asymptomatic and may not be recognized clinically, subsequent chronic infection is usually life-long and may lead to significant chronic liver disease leading to cirrhosis of the liver and hepatocellular carcinoma.

$\mathrm{HCV}$ infection is an emerging health problem in Myanmar. HCV carriers were detected in $2.5 \%$ of apparently healthy individuals, in $24.9 \%$ of patients with

\footnotetext{
*Corresponding author. Mailing addresss: Takashi Shimada, Central Research Laboratories, Nichinichi Pharmaceutical Corporation Ltd., 239-1 Tominaga, Iga City, Mie 518-1417, Japan. Phone: +81-595-48-0201, Fax: +81-595-48-0209. E-mail: lab@ nichinichi-phar.co.jp

(C)2016 BMFH Press

This is an open-access article distributed under the terms of the Creative Commons Attribution Non-Commercial No Derivatives (bync-nd) License $<$ http://creativecommons.org/licenses/by-nc-nd/4.0/>.
}

liver diseases [1] and in 35\% of hepatocellular carcinoma (HCC) cases [2]. Once infected with $\mathrm{HCV}$, the proportion of patients who develop chronic liver disease exceeds $80 \%$, and up to $20 \%$ of chronic HCV cases may progress to liver cirrhosis: $1-5 \%$ could develop $\mathrm{HCC}$ within a period of 20-30 years [3]. Until 2002, there were no $\mathrm{HCV}$ screening available. After a vigorous campaign starting in 2000, screening for transfusion blood became the routine.

The treatment options for chronic $\mathrm{HCV}$ infection include monotherapy with interferon alpha/beta subtypes or in combination with antiviral drugs, which are considered the first line treatment for chronic $\mathrm{HCV}$ infection. However, this therapy is expensive and associated with the development of dose-related side effects. Economic burden of social as well as personal would be enormous without stopping the progression of the diseases.

Extensive immunological studies of microorganisms have revealed that preparations of whole cells or cell walls from several bacterial species that constituted the microbial flora are effective in potentiating the immune 
response when administered parenterally in experimental animals and humans. This stimulated research and development on some of these bacterial preparations or their derivatives as biological response modifiers (BRMs) which are useful in cancer therapy [4], which is also known as cancer immunotherapy [5].

The term "probiotics" was defined in 1989 by Fuller as "live organisms that show health effects on host animal by altering the balance of intestinal bacteria" [6] and was defined by Salminen et al. in 1998 as "food which contain live bacteria which are beneficial to health" [7]. Studies indicating that oral administration of lactic acid bacteria including Lactobacillus, Bifidobacterium and Enterococcus has various physiological activities and has been shown to have effects on rotavirus gastroenteritis [8] and acute infectious diarrhea [9], protection against Helicobacter pylori infection [10], inhibitory effects on tumor cells [11], and anti-hypertension [12], antihyperlipemia [13] and anti-allergy effects [14].

Several bacterial strains derived from intestinal flora have been developed as commercial food products, and among them is Enterococcus faecalis strain FK-23, one of the lactic acid bacteria isolated from healthy human feces. Functional foods containing FK-23 are made by the Nichinichi Pharmaceutical Co., Ltd., in Japan. The bacteria in the functional foods are not live but instead are heatkilled at $110^{\circ} \mathrm{C}$ to prepare them as a probiotic supplement.

This study was carried out to determine the safety and long-term effect of the probiotic FK-23 in patients with hepatitis $\mathrm{C}$ virus infection.

\section{SUBJECTS AND METHODS}

\section{Study design}

This study was carried out as a single-arm, noncomparative clinical drug trial study at the Department of Medical Research (Lower Myanmar), Yangon, Myanmar from 2010 to 2013, after obtaining permission from the Institutional Ethical Committee of the Department of Medical Research (Lower Myanmar).

\section{Subjects}

The subjects were healthy and asymptomatic male and female adult volunteers who were serologically positive for anti-HCV IgG antibodies, are 18-60 years of age, ALT levels of $\geq 50 \mathrm{IU} / \mathrm{ml}$ and were recruited from 260 individuals who visited the Hepatitis Carrier Clinic, Department of Medical Research (Lower Myanmar), and were positive for anti-HCV antibodies. All subjects received an explanation about the objective and procedure of the study, and only those who gave voluntary consent were recruited. All subjects were informed that they had the right to withdraw from the study at any stage. Exclusion criteria included (a) daily alcohol consumption of more than $60 \mathrm{~g}$, (b) heavy smoking (more than 15 cigarettes or $30 \mathrm{~g}$ of tobacco/day), (c) liver diseases (cirrhosis and hepatocellular carcinoma), (d) HBV infection, (e) HIV infection, (f) pregnancy, (g) lactation, and (h) history of taking any oral antioxidant therapy during the 3-month period prior to enrollment.

\section{Procedure}

A complete medical history was taken, which was followed by complete physical examination of all subjects to obtain a baseline data. All participants were subjected to ultrasonography (abdominal scan) to exclude liver cirrhosis and/or hepatocellular carcinoma. Serological tests were done to exclude HBV and HIV infections.

Anti-HCV seropositivity was determined with an immunochrmatic test kit from Standard Diagnostics Inc, Yongin, Republic of Korea, and confirmed by enzymelinked Immunosorbent assay (ELISA). A clinical chemistry photometer (Analyzer 90, DAS, Rome, Italy) was used for determination of urea, total protein and the liver enzymes alanine aminotransferase (ALT) and asparate aminotransferase (AST). Hematological parameters including hemoglobin and platelet count were determined with a PENTRA-60 Automatic Blood Cell Analyzer. Testing of viral load was carried out at Medic Co., Ltd. (Mie, Japan).

\section{Assessment}

The duration of the study was 36 months, and blood samples were taken at enrollment and every 3 months and tested for ALT and AST levels. Determination of viral load and hematological (hemoglobin and platelet count) and biochemical parameters (urea, total protein) was done every 6 months.

\section{Probiotic (FK-23)}

Each patient was given 2,700 mg of FK-23 per day (1 sachet 3 times daily) by oral route. Ingredients of one sachet of sample food contained $900 \mathrm{mg}$ of FK-23 lactic acid bacteria powder, $255 \mathrm{mg}$ of soy protein, $240 \mathrm{mg}$ dextrin and $105 \mathrm{mg}$ of corn starch.

\section{Statistical analysis}

Statistical analysis was carried out using MINITAB 14.1 (Minitab Corporation, State College, PA, USA). Descriptive statistics were used for continuous variables and presented as the mean and standard deviation. A $\mathrm{p}$ value of $<0.05$ was considered significant. 
Table 1. Change in ALT and AST levels after probiotic therapy

\begin{tabular}{|c|c|c|c|c|c|}
\hline Months of therapy & $\begin{array}{l}\text { No. of } \\
\text { subjects }\end{array}$ & $\begin{array}{c}\text { Mean ALT } \pm \text { SD } \\
(\mathrm{IU} / \mathrm{L})\end{array}$ & $\mathrm{p}$ value & $\begin{array}{c}\text { Mean AST } \pm \text { SD } \\
(\mathrm{IU} / \mathrm{L})\end{array}$ & $\mathrm{p}$ value \\
\hline Initial & 39 & $64.8 \pm 17.5$ & & $64.3 \pm 28.7$ & \\
\hline $3 \mathrm{M}$ & 39 & $34.9 \pm 15.1$ & 0.000 & $63.2 \pm 33.7$ & NS \\
\hline $6 \mathrm{M}$ & 37 & $27.9 \pm 13.0$ & 0.000 & $51.6 \pm 29.2$ & NS \\
\hline $9 \mathrm{M}$ & 36 & $31.6 \pm 21.1$ & 0.000 & $46.2 \pm 21.7$ & 0.006 \\
\hline $12 \mathrm{M}$ & 35 & $27.1 \pm 14.5$ & 0.000 & $46.6 \pm 17.9$ & 0.002 \\
\hline $15 \mathrm{M}$ & 33 & $36.5 \pm 27.8$ & 0.000 & $47.1 \pm 21.8$ & 0.008 \\
\hline $18 \mathrm{M}$ & 31 & $32.7 \pm 21.2$ & 0.000 & $42.7 \pm 20.1$ & 0.000 \\
\hline $21 \mathrm{M}$ & 31 & $40.0 \pm 43.0$ & 0.002 & $43.5 \pm 22.5$ & 0.002 \\
\hline $24 \mathrm{M}$ & 31 & $42.9 \pm 31.3$ & 0.000 & $53.5 \pm 47.0$ & NS \\
\hline $27 \mathrm{M}$ & 28 & $32.0 \pm 23.2$ & 0.000 & $46.1 \pm 31.9$ & 0.012 \\
\hline $30 \mathrm{M}$ & 24 & $39.3 \pm 21.3$ & 0.009 & $44.5 \pm 20.6$ & 0.009 \\
\hline $33 \mathrm{M}$ & 24 & $56.0 \pm 39.1$ & NS & $59.4 \pm 39.8$ & NS \\
\hline $36 \mathrm{M}$ & 23 & $43.7 \pm 25.2$ & 0.003 & $60.1 \pm 43.4$ & NS \\
\hline
\end{tabular}

NS: not significant.

Table 2. Treatment effect of FK-23 on ALT level in HCV patients

\begin{tabular}{|c|c|c|c|c|c|c|c|c|c|}
\hline & \multicolumn{2}{|c|}{0 month } & \multicolumn{2}{|c|}{12 months } & \multicolumn{2}{|c|}{24 months } & \multicolumn{2}{|c|}{36 months } & \multirow{2}{*}{ Change } \\
\hline & $\mathrm{UI} / \mathrm{L}$ & $\mathrm{n}$ & $\mathrm{UI} / \mathrm{L}$ & $\mathrm{n}$ & $\mathrm{UI} / \mathrm{L}$ & $\mathrm{n}$ & $\mathrm{UI} / \mathrm{L}$ & $\mathrm{n}$ & \\
\hline \multirow{3}{*}{ Mean $\pm \mathrm{SD}$} & $62.5 \pm 10.7$ & 25 & $26.6 \pm 14.9$ & 25 & $24.8 \pm 15.4$ & 16 & $35.7 \pm 12.4$ & 15 & Improved \\
\hline & & & & & $66.7 \pm 20.6$ & 3 & $69.6 \pm 0$ & 1 & No \\
\hline & & & & & $86.2 \pm 13.1$ & 5 & $96.9 \pm 24$ & 8 & Worsened \\
\hline
\end{tabular}

\section{RESULTS}

\section{Subjects}

From subjects who visited the Hepatitis Carrier Clinic, Department of Medical Research (Lower Myanmar), and were positive for anti-HCV antibodies, 46 subjects (23 males and 23 females) who fulfilled the selection criteria and gave voluntary consent were initially recruited for the study. Due to the dropout of 7 ( 4 male, 3 female) recruits for various reasons, only 39 (19 males, 20 females) subjects participated in the study. The mean age of the subjects was $45.0 \pm 7.9$ years, with no significant difference between males and females $(43.3 \pm 8.6$ versus $41.5 \pm 9.1$ years $)$.

\section{Alanine aminotransferase (ALT) and aspartate aminotransferase (AST) levels}

The initial mean ALT level of the subjects was $64.8 \pm$ 17.5 IU/1. Significant decreases in mean ALT levels were observed at 3 months $(34.9 \pm 15.1 \mathrm{IU} / 1)$ as compared with the initial level $(64.8 \pm 17.5 \mathrm{IU} / \mathrm{l})$ and persisted up to 36 months $(43.7 \pm 25.2 \mathrm{IU} / \mathrm{l})$ (Table 1$)$. The baseline mean AST level of the subjects was $64.3 \pm 28.7 \mathrm{IU} / 1$. Significant decrease of AST was detected at 9 months $(46.2 \pm 21.7$ IU/1) of probiotic therapy as compared with the baseline $(\mathrm{p}=0.006)$ and persisted up to 30 months $(44.5 \pm 20.6$ IU/l, $\mathrm{p}=0.009$ ) (Table 1).

The initial mean ALT level of 25 subjects was $62.5 \pm$ 10.7 IU/1. Significant decreases in mean ALT levels were observed at 12 months $(26.6 \pm 14.9 \mathrm{IU} / 1)$ as compared with the initial level $(62.5 \pm 10.7 \mathrm{IU} / \mathrm{l})$. It persisted in 15 of 24 subjects up to 36 months $(35.7 \pm 12.4 \mathrm{IU} / 1)$. It returned to its original state $(69.6 \pm 0 \mathrm{IU} / 1)$ in 1 subject within the month. An increase was observed in 8 subjects within the same month $(96.9 \pm 24.0 \mathrm{IU} / \mathrm{l})$ (Table 2).

\section{Viral load}

The mean viral load of the subjects at the initial recruitment was $5.5 \pm 1.0 \mathrm{log} \mathrm{IU} / \mathrm{ml}$, with no significant changes at 6 months $(5.2 \pm 1.1 \log \mathrm{IU} / \mathrm{ml}), 12$ months $(5.3 \pm 1.2 \log \mathrm{IU} / \mathrm{ml}), 18$ months $(5.3 \pm 1.2 \log \mathrm{IU} / \mathrm{ml})$, 24 months $(5.3 \pm 0.9 \log \mathrm{IU} / \mathrm{ml}), 30$ months $(5.6 \pm 0.9 \log$ $\mathrm{IU} / \mathrm{ml})$ and at 36 months $(5.7 \pm 0.9 \log \mathrm{IU} / \mathrm{ml})$, indicating that FK-23 had no effect on the mean viral load of the subjects (Fig. 1).

\section{Biochemical parameters}

The initial mean urea and total protein levels of the subjects were $20.2 \pm 6.0 \mathrm{mg}$ and $7.5 \pm 0.6 \mathrm{mg} / \mathrm{dl}$. No significant changes were observed in the mean urea and 
Table 3. Biochemical and hematological parameters

\begin{tabular}{lccccccc}
\hline Parameters Mean $\pm \mathrm{SD}$ & $0 \mathrm{M}$ & $6 \mathrm{M}$ & $12 \mathrm{M}$ & $18 \mathrm{M}$ & $24 \mathrm{M}$ & $30 \mathrm{M}$ & $36 \mathrm{M}$ \\
\hline Hemoglobin $(\mathrm{g} / \mathrm{dl})$ & $13.8 \pm 2.7$ & $13.8 \pm 2.1$ & $14.3 \pm 2.3$ & $13.7 \pm 2.3$ & $13.1 \pm 2.3$ & $13.3 \pm 2.2$ & $13 \pm 1.9$ \\
Platelet count $\left(\times 10^{3} / \mathrm{mm}^{3}\right)$ & $192.9 \pm 72.8$ & $210.2 \pm 76.8$ & $216.4 \pm 82.7$ & $217.6 \pm 82.4$ & $209.5 \pm 94.3$ & $212.8 \pm 98.4$ & $209.0 \pm 102.3$ \\
Urea $(\mathrm{mg} \%)$ & $20.2 \pm 6.0$ & $20.1 \pm 7.6$ & $25 \pm 9.0$ & $25.7 \pm 11.6$ & $27.4 \pm 10.4$ & $26.5 \pm 7.0$ & $26.6 \pm 9.9$ \\
Total protein $(\mathrm{g} / \mathrm{dl})$ & $7.5 \pm 0.6$ & $7.3 \pm 0.83$ & $7.4 \pm 0.7$ & $7.1 \pm 0.8$ & $7.2 \pm 0.7$ & $6.9 \pm 0.8$ & $6.7 \pm 0.6$ \\
\hline
\end{tabular}

M: months.

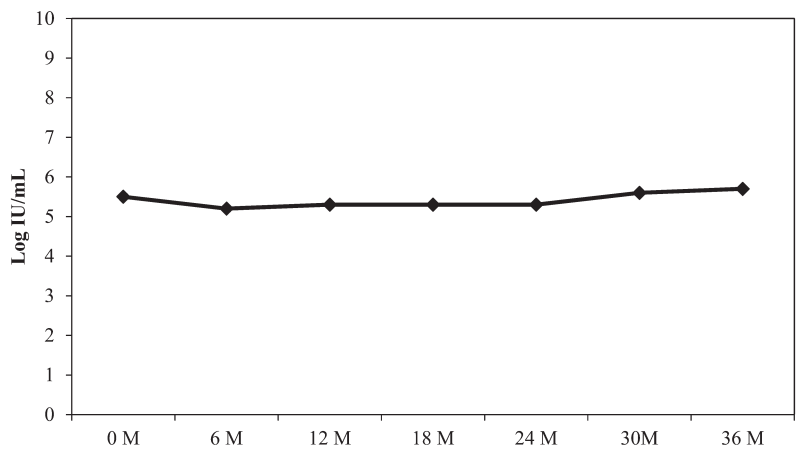

Fig. 1. Change in mean viral load levels.

protein levels of the subjects at 12, 24 and 36 months of probiotic therapy (Table 3 ).

\section{Hematological parameters}

The initial mean hemoglobin level was $13.8 \pm 2.7 \mathrm{~g} / \mathrm{dl}$, and the mean platelet count of the subjects was $192.9 \pm$ $72.8 \times 10^{3} / \mathrm{mm}^{3}$. FK-23 did not affect the hematological parameters of the subjects at 12, 24 and 36 months of therapy (Table 3).

\section{Side effects}

FK-23 was well tolerated by the participants. There were no serious side effects apart from complaints of transient giddiness and headache by $4 \%$ of the participants and mild constipation in less than $8 \%$ of the participants.

\section{Safety of probiotic therapy}

The safety of FK-23 was evident, as no significant changes were detected in the hematological (hemoglobin level and platelet count) and biochemical parameters (urea and total protein levels) and there were no untoward side effects.

\section{DISCUSSION}

The problem of HCV infection in Myanmar is well recognized, and efforts to control it in the blood donor population were initiated in 2000 [15]. Screening of
154,161 blood donors from May 2000 to April 2004 demonstrated that the prevalence of $\mathrm{HCV}$ infection among Myanmar blood donors was 2.6\% [16]. Management of chronic hepatitis $\mathrm{C}$ infection has included antiviral drugs, iron reduction therapy, antioxidants, cytokines, immunomodulators (including BRMs and probiotics) and herbal remedies.

Probiotic bacteria have well-established beneficial effects in the management of diarrheal diseases. New evidence suggests that probiotics have the potential to reduce the risk of developing inflammatory bowel diseases and intestinal bacterial overgrowth after gut surgery. In liver health, the main benefits of probiotics might occur through preventing the production and/or uptake of lipopolysaccharides in the gut and therefore reducing levels of low-grade inflammation [17]. Individuals with cirrhosis of the liver are often found to have an imbalance of the intestinal microbiota. Known as beneficial bacteria, probiotics help maintain balance in the gut by reducing the growth of harmful bacteria, keeping the intestines healthy, assisting in food digestion and supporting immune function. There are studies that have suggested that probiotics should be included into the routine therapy for patients struggling with the hepatitis $\mathrm{C}$ drug side effects of fatigue, nausea and low appetite [18]. The primary mechanisms reported in these studies are the changes in gut functions. Controlling the microbiota quantity can lead to decreased endotoxins and other toxic compounds derived from bacteria such as ethanol, phenol and indoles which cause injury to the liver [19].

This study was carried out to study the safety and long-term effect of probiotic Enterococcus faecalis strain FK-23, one of the lactic acid bacteria abundant in the human intestinal tract. In our study, the liver enzymes ALT and AST were determined every three months. The findings showed that significant decreases in mean ALT levels were observed at 3 months and persisted up to 36 months. In contrast, significant decrease of the AST level was detected only at 9 months of therapy $(62.13 \pm 28.11$ versus $46.22 \pm 21.65 \mathrm{IU} / \mathrm{l})$. This might be due the fact that AST is present in a diversity of tissues such as the liver, 
heart, muscle, kidney and brain and the fact that damage to any of these may result in increase of the enzyme level. These results suggested that oral administration of FK-23 is specially effective for the liver.

No significant changes were detected in the hematological (hemoglobin level and platelet count) and biochemical parameters (urea and total protein levels) of the subjects during the study period of 36 months, thus indicating the safety of FK-23 (Table 2). As probiotics are not antiviral agents, changes of the mean viral load of the subjects were not expected during therapy. The findings showed that there were no significant changes of viral load at 12, 24 and 36 months (Fig. 1).

Findings from a previous study indicated the clinical efficacy of FK-23 preparation for the liver function of patients suffering from active chronic hepatitis C. Blood samples were collected before and at 3 and 6 months after administration of the preparation, and the serum aminotransferase (AST and ALT) levels were determined. Improvement of liver function was observed in 8 out of 9 patients [20].

There have been reports that oral administration of FK-23 reduced the levels of ALT and glucose in sera as well as the accumulation of lipid in the liver in a high-fat diet-induced hepatic steatosis mice model [21]. Hepatic steatosis is known to eventually develop into cirrhosis leading to $\mathrm{HCC}$, and the progression is similar to that of $\mathrm{HCV}$ infection [22]. Although the causes of active chronic hepatitis $\mathrm{C}$ and hepatic steatosis are different from each other, the ALT level in sera was improved in both cases. This suggests that FK-23 has a general protective effect on hepatocytes.

Recent publications indicated the relationships between liver function and the translocation of bacterial components from the intestinal tract. Intestinal bacterial overgrowth and changes in the composition of the intestinal microbiota may also promote bacterial translocation [23]. Increased translocation of microbiota and bacterial products, such as LPS and PGN, from the intestinal tract may enhance liver inflammation through activation of the innate immune system. Indeed, elevated LPS levels in the systemic and portal circulation have been reported in patients with cirrhosis [24]. Previously, we demonstrated that oral administration of FK-23 regulates the balance of the intestinal microflora [25]. Therefore, oral administration of FK-23 might change the microbiota in hepatitis $\mathrm{C}$ patients, and this might be the one of the mechanisms of the decrease in serum ALT. Further analysis is required for a comprehensive understanding of the mechanisms.

Probiotic research is moving forward on two fronts, basic science (laboratory studies) and clinical trials, to evaluate the safety and efficacy of probiotics for various medical conditions. Probiotic administration is safe, inexpensive and a noninvasive strategy as compared with antibiotic therapy and surgery. A limitation of our study was the inability to demonstrate the effect of probiotics on the histopathological changes in the liver tissues of the subjects, as liver biopsy is not routinely performed in Myanmar.

Findings from our study indicated that the candidate probiotic FK-23 was safe and well tolerated by the participants, and the majority of subjects reported a sense of well-being during the probiotic therapy.

\section{CONCLUSION}

As the probiotic FK-23 therapy was safe, noninvasive and well-tolerated by the subjects, with no major sideeffects, consideration should be given to include probiotics as an alternative therapy for patients with hepatitis $\mathrm{C}$ virus infection.

\section{REFERENCES}

1. Kyi PK, Win KM. 1995. Viral hepatitis in Myanmar. DMR Bull 9: 1-31.

2. Kyi PK, Win KM, Aye M, Htwe YY, Oo KM, Aung T, Oo SS. 1998. Prevalence of hepatitis B and C infection in hepatocellular carcinoma cases in Myanmar. Myanmar Health Sci Res J 10: 1-5.

3. Win KM. 2000. Clinical aspect of hepatitis C infection. Proceeding of Seminar on Control of Hepatitis C in Myanmar: 6-10.

4. Gupta S, Kanodia AK. 2002. Biological response modifiers in cancer therapy. Natl Med J India 15: 202-207. [Medline]

5. Huber CH, Wölfel T. 2004. Immunotherapy of cancer: from vision to standard clinical practice. J Cancer Res Clin Oncol 130: 367-374. [Medline] [CrossRef]

6. Fuller R. 1989. Probiotics in man and animals. J Appl Bacteriol 66: 365-378. [Medline] [CrossRef]

7. Salminen S, von Wright A, Morelli L, Marteau P, Brassart D, de Vos WM, Fondén R, Saxelin M, Collins K, Mogensen G, Birkeland SE, Mattila-Sandholm T. 1998. Demonstration of safety of probiotics-a review. Int J Food Microbiol 44: 93-106. [Medline] [CrossRef]

8. Majamaa H, Isolauri E, Saxelin M, Vesikari T. 1995. Lactic acid bacteria in the treatment of acute rotavirus gastroenteritis. J Pediatr Gastroenterol Nutr 20: 333 338. [Medline] [CrossRef]

9. Fedorak RN, Madsen KL. 2004. Probiotics and prebiotics in gastrointestinal disorders. Curr Opin Gastroenterol 20: 146-155. [Medline] [CrossRef] 
10. Sakamoto I, Igarashi M, Kimura K, Takagi A, Miwa T, Koga Y. 2001. Suppressive effect of Lactobaccilus gasseri OLL 2716 (LG 21) on Helicobacter pylori infection in humans. J Antimicrob Chemother 47: 709-710. [Medline] [CrossRef]

11. Kato I, Endo K, Yokokura T. 1994. Effects of oral administration of Lactocbaccilus casei on anti-tumor responses induced by tumor resection in mice. Int $\mathrm{J}$ Immunopharmacol 16: 29-36. [Medline] [CrossRef]

12. Jauhiainen $T$, Vapaatalo $H$, Poussa $T$, Kyrönpalo S, Rasmussen M, Korpela R. 2005. Lactobacillus helveticus fermented milk lowers blood pressure in hypertensive subjects in 24 hour ambulatory blood pressure measurement. Am J Hypertens 18: 16001605. [Medline] [CrossRef]

13. Ooi LG, Liong MT. 2010. Cholesterol-lowering effects of probiotics and prebiotics: a review of in vivo and in vitro findings. Int J Mol Sci 11: 2499-2522. [Medline] [CrossRef]

14. Shimada T, Cheng L, Enomoto T, Yang X, Miyoshi A, Shirakawa T. 2004. Lysed Enterococcus faecalis FK-23 oral administration reveals inverse association between tuberculin response and clinical manifestations in perennial allergitis rhinitis: a pilot study. J Investig Allergol Clin Immunol 14: 187-192. [Medline]

15. Myo-Khin, San-San-Oo, Oo KM, Shimono K, Koide N, Okada S. 2010. Prevalence and factors associated with hepatitis $\mathrm{C}$ virus infection among Myanmar blood donors. Acta Med Okayama 64: 317-321. [Medline]

16. Khin M, Swe TN. 2003. Contributions by the Japan International Cooperation Agency to hepatitis $\mathrm{C}$ control and research in Myanmar. DMR Bull 17: 1-17.

17. Gratz SW, Mykkanen H, El-Nezami HS, Nezami E. 2010. Probiotics and gut health: a special focus on liver diseases. World J Gastroenterol 16: 403-410. [Medline] [CrossRef]
18. Nicole CL. 2010. Could probiotics help those with hepatitis C. Retrieved from http:www.hepatitiscentral. com/mHarchives/2010/12/.

19. Imani Fooladi AA, Mahmoodzadeh Hosseini H, Nourani MR, Khani S, Alavian SM. 2013. Probiotic as a novel treatment strategy against liver disease. Hepat Mon 13: e7521. [Medline] [CrossRef]

20. Maki N, Nohmi T, Shimada T, Yajin S, Yoda S, Ikeda H, Enomoto T. 2004. Efficacy of heat-treated Enterococcus faecalis FK-23 preparations on serum aminotransferase levels in patients with chronic type C hepatitis. Journal of the Japan Red Cross Society, Wakayama Medical Center 22: 19-24.

21. Kondoh M, Shimada T, Fukada K, Morita M, Katada K, Higashimura Y, Mizushima K, Okamori M, Naito Y, Yoshikawa T. 2014. Beneficial effects of heat-treated Enterococcus faecalis FK-23 on high-fat diet-induced hepatic steatosis in mice. Br J Nutr 112: 868-875. [Medline] [CrossRef]

22. Zafrani ES. 2004. Non-alcoholic fatty liver disease: an emerging pathological spectrum. Virchows Arch 444: 3-12. [Medline] [CrossRef]

23. Son G, Kremer M, Hines IN. 2010. Contribution of gut bacteria to liver pathobiology. Gastroenterol Res Pract 2010: 453563. [Medline] [CrossRef]

24. Chan CC, Hwang SJ, Lee FY, Wang SS, Chang FY, Li CP, Chu CJ, Lu RH, Lee SD. 1997. Prognostic value of plasma endotoxin levels in patients with cirrhosis. Scand J Gastroenterol 32: 942-946. [Medline] [CrossRef]

25. Shimada T, Cheng L, Shi HB, Hayashi A, Motonaga C, Tang J, Enomoto K, Enomoto T. 2007. Effect of lysed Enterococcus faecalis FK-23 on allergeninduced immune responses and intestinal microflora in antibiotic-treated weaning mice. J Investig Allergol Clin Immunol 17: 70-76. [Medline] 